Hooker and he would have strengthened the hands of those who wish to see science represented in our higher education, and the addition of their names would certainly not have upset the balance of the Commission, as Prof. Price, Dr. Bateson, and Prof. Max Müller, would have adequately maintained the interests of the older studies. Surely, when we are setting about the reform of our universities, we want all available information about the systems of foreign countries, and Prof. Max Muiller could have told the Commissioners many things they have not learnt from their own experience of Oxford and Cambridge. The refusal of the Government to add any names to the criginal list was an unfortunate sign of the spirit in which they have framed it, and of the attitude in which the Commissioners will face the problems before them. Ministers were successful, but their majorities were so small as to show that the sense of the few members who will not consent as partisans to vote on such questions was decidedly against them. They carried their point by II, $34,24,26,32$ votes on the successive divisions. After their success nobody will care much what becomes of a bill which is meant to change as little as possible, when every crevice that could let in light from the outsicle world is carefully stopped against it.

The speech of the Secretary of War, who is Member for the University of Oxford, and the general tone of the debate, clearly confirm these anticipations. There will be a slight restriction of the "prize fellowships," the new Government name for the "idle fellowships" of L.ord Salisbury, There will not be a great extension of the professoriate, provision even having been made for the amalgamation of several professorships into one. Some money5 per cent. from some colleges, to per cent. from others, nothing perhaps from a third class-will be taken from the colleges for university purposes. There is a provision "for the extension, not for the suppression," of scholarships. Only the superfiuities of the colleges are to go to the University, and Mr. Hardy has never had but one opinion on "what some people called the endowment of research." He did not state that opinion so frankly as Mr. Trevelyan, but there was little doubt from the tone of his remarks that it was substantially the same :-

"It was a mistake, therefore, to assume that we could create in men such qualities by merely endowing old men, and in his opinion it would be better to throw the funds of the Universities into the sea rather than to bestow them in the manner which had been proposed. The people whose prayers the House should listen to were the practical teachers of the University, who were bound to celibacy, and who asked them to make their career a better one, to give them a reasonable income, and to allow them to marry without being compelled to resign their positions. These gentlemen would have six months in the year, which they would be able to devote to the pursuit of science and literature. What they had to do was to find men for the places, and not places for the men. He begged them to consider well before they created a sort of hierarchy of sinecures and semi-sinecures which unless human nature was radically altered by this Bill would only lead to academical jobbery and intellectual stagnation."

No doubt the wholesale conversion of the fellowships of residents and, for that matter, of non-residents into professorships, created in a doctrinaire spirit, and apart from the gradual development of literature and science, would be recklessness and folly. Nobody in his senses wants such a thing. The real note of despair in the whole debate is that Oxford and Cambridge wish to be let alone, and Oxford and Cambridge men in the House are determincd that they shall be let alone to consider every question as it comes up from the mere lacal point of view of Oxford and Cambridge. The jealous exclusion of outsiders is the surest proof of the intention of the framers of the bill and the clearest prophecy of its issues.

The Committee made no real alterations in the bill. There was a desperate attempt to main it by striking out even the possibility of endowments for research. It was resisted and defeated by an overwhelming majority. Mr. Hardy said "the noble lord and the hon. gentleman seemed to be under the apprehension that if research were brought into the University education would be driven out. On the contrary, he held that no teaching could be successful that was not founded on the most minute research. There were, no doubt, many subjects of research which by their nature were not lucrative to those who prosecuted them but the prosecution of which was of great importance to education throughout the country, and especially to the University in which they were carried on. There was, however, no intention to carry research to the extravagant lengths which some speakers and writers feared would be the case, and which would utterly pervert the purposes of the University. So far from diminishing the educational power of the University, that which was proposed would give to education a more solid basis than it now possessed." Mr. Trevelyain accepted Mr. Hardy's statement as "in all respects satisfactory," and added a remarl none the less valuable that it is almost a truism, "They could not have a University where education was proceeding without research proceeding at the same time." The Commissions will thus be left at liberty to use the funds they can detacis from the Colleges for the endowment of research. Bui "Researchers," as Prof. Sylvester calls them, will not for many years to come, grow very fat on the good things of Oxford and Cambridge.

\section{DEEP WELL-BORINGS IN LONDON}

THE constantly increasing wants of our English metro. polis were very amply provided for during all the earlier stages of its history by the stores of water contained in the extensive beds of gravel lying within the Thames Valley. These stores of water could be reached by means of shallow wells, and all the ancient and famous pumps of our city drew their supplies from this source.

But, as the population of the district increased, the value of this source of water-supply became greatly impaired from two causes; firstly, the excessive drain upon it, caused by the rapid multiplication of wells; and secondly, the pollution of its waters by the refuse-matter of a great city.

Hence it became necessary to seek for new sources of water-supply, and the success which had already attended the construction of Artesian wells in the Tertiary districts of Northern France, led to attempts being made to obtain supplies in a similar manner by putting down borings through the impervious London Clay into the wates. bearing beds of the Lower London Tertiaries. 
For a time the quantity of water thus obtained, as at Merton, Garrett, and many other points, seem to have induced the belief that an inexhaustible source of the allessential element had been discovered; but the rapid multiplication of these Artesian wells soon revealed the fact that the new and valuable stores had their limit, and that this limit was being very rapidly approached in consequence of the excessive demands which were now being made upon the new source of supply. The deepening of the wells, by which means water was drawn from the Chalk, as well as from the Tertiary strata, promised, however, to do something towards staving off the evil day when London would no longer be able to depend on drafts being honoured by her great subterranean bank.

Such was the state of the question when Mr. Prestwich, now the Professor of Geology in the University of Oxford, undertook its complete investigation as an important geological problem. No one more competent for the task could possibly have been found, for during many years Mr. Prestwich's studies had been devoted to the Tertiary deposits of the London and Hampshire basins ; and his great work-" A Geological Inquiry respecting the Water-bearing Strata of the country around London, with Reference especially to the Water-supply of the Metropolis," which was published in $185 \mathrm{I}$-is a masterpiece of minute observation and close and accurate reasoning.

More than this, the geologist points to the work with pardorabie pride, as affording convincing proof that his science has now acquired a character for exactness, analogous to that which is justly regarded as the crowning attribute of astronomy. After a most elaborate study of the nature and relations of the various strata which crop out all round the London Basin and of the disturbances to which they have been subjected since their deposition, Mr. Prestwich ventured on a bold prediction, namely, that the Chalk beneath London would be found to have a thickness of 650 feet, the Upper Greensand of 40 feet, and the Gault of 150 feet. (OD. cit. p. r42.)

At the time when this announcement was made no well in London had been sunk to a greater depth than 300 feet in the Chalk, but now we can appeal to no less than four deep borings in the metropolis, which afford the most convincing proof of the reliability of the data, and the accuracy of the reasoning by which $\mathrm{Mr}$. Prestwich arrived at his interesting results. For the sake of distinctness, we place the estimated and determined results side by side in a tabular form :-

\begin{tabular}{|c|c|c|c|c|}
\hline Mr. Prestwich's Estimate. & $\begin{array}{l}\text { Boring at } \\
\text { Kentish } \\
\text { Town. }\end{array}$ & $\begin{array}{l}\text { Boring at } \\
\text { Crossness. }\end{array}$ & $\begin{array}{l}\text { Poring at } \\
\text { Loughton. }\end{array}$ & $\begin{array}{l}\text { Boring at } \\
\text { Meux's } \\
\text { Brewery. }\end{array}$ \\
\hline Chalk .............650 & 645 & 646 & 650 & 653 \\
\hline Upper Greensand $\quad 40$ & $13 \frac{1}{2}$ & 12 & 40 & 28 \\
\hline Gault $\ldots \ldots \ldots \ldots \ldots \ldots$ I50 & I $30 \frac{1}{2}$ & 148 & (?) & 159 \\
\hline
\end{tabular}

When it is remembered that the Chalk graduates downwards insensibly into the Upper Greensand, and that it is almost impossible to decide on their line of separation in the cores brought up by boring operations, it will be admitted on all hands that the agreement between the estimated and proved results is marvellously close.

One of the most important conclusions of Mr. Prestwich's work was that the strata below the Gault, the so- called "Lower Greensand," would in the future afford a most valuable underground source of water-supply to our overgrown city.

But in I855 Mr. Godwin-Austen brought before the Geological Society of London his masterly essay "On the Possible Extension of the Coal-Measures beneath the South-Eastern Part of England," in which he announced the conclusion-based on a most elaborate study of the geological structure of the South of England and the adjoining portions of the Continent of Europe-that an old ridge of Palreozoic rocks underlies the line of the Thames Valley, and is only concealed from us by the Upper Cretaceous strata.

Mr. Godwin-Austen's announcement was as strikingly verified as was that of Mr. Prestwich; for, in the same year that it was made, a boring at Kentish Town which passed through the Gault, reached a curious series of red rocks which are now believed by geologists to be either a portion of the old Palreozoic ridge itself, or a set of littoral deposits formed upon its flanks. And in 1857 the deep boring at Harwich afforded still more unmistakable evidence of the existence of this old Palæozoic ridge in the fact that black slaty rocks were found immediately below the Gault clay.

Although the old ridge of Palæozoic rocks must thus limit the area of the available water-bearing "Lower Greensand" beneath the metropolitan district, yet Prof. Prestwich has constantly argued that very large and valuable supplies of water will yet in all probability be obtained from the latter source.

Hence it is that the endeavour to tap this great subterranean reservoir, which is now being carried out in such an enterprising spirit by the Messrs. Meux and Co., in the Tottenham Court Road, is attracting so much attention from ge logists and engineers. The nodular bells at the base of the Gault were reached at a depth of 999 feet from the surface, and some sixty feet of rock below has since been penetrated. The splendid cores brought up by the diamond-borer are at once submitted to $\mathrm{Mr}$. Robert Etheridge, the palæontologist of the Geological Survey, who is carefully studying every trace of fossils which they exhibit. At present there are very strong grounds for believing that the "Lower Greensand" has been reached, and we soon hope to be able to announce that the new source of water supply, so long ago pointed out by Prof. Prestwich, has at last been made available for the ever-increasing necessities of this great city.

\section{J. W. JUDD}

\section{LATHAM'S ENGLISH DICTIONARY}

$A$ Dictionary of the English Language. Abridged by the Editor from that of Dr. Samuel Johnson, as Edited by Robert Gordon Latham, M.A., M.D., \&c. (London: Longmans and Co., I876.)

W English dictionary in these pages for two reasons first, because the method of its construction ought to be rigidly scientific, and second, because a large proportion of the words in any modern English dictionary must necessarily be scientific terms.

It is admitted by all competent to pronounce an opinion that there is ample room for a new dictionary of the 